\title{
O DIREITO INDIGENISTA NO BRASIL: TRANSFORMAÇÕES E INOVAÇÕES A PARTIR DA CONSTITUIÇÃ FEDERAL DE 1988
}

\author{
Julianne Holder da Camara Silva Feijó ${ }^{1}$
}

\begin{abstract}
RESUMO
Nascida em meio ao processo de redemocratização brasileira e fortemente influenciada por valores multiculturais, a Constituição Federal de 1988 consolidou no Estado brasileiro o fenômeno neoconstitucional, colocando a dignidade humana como seu valor nuclear a se irradiar por todo o ordenamento jurídico. Essencialmente pluralista, a Constituição de 88 realizou uma transformação sem precedentes no universo do direito indigenista, abandonando definitivamente o paradigma da assimilação cultural dos índios e reconhecendo sua identidade cultural como algo indissociável da materialização de sua dignidade humana. Nesse contexto, serão estudadas as diversas modificações na estrutura jurídica brasileira, no que se refere à tutela do ser indígena, introduzidas a partir dessa reformulação constitucional que influenciou decisivamente não só a atuação legislativa como a postura dos nossos Tribunais quando na resolução de delicadas questões envolvendo os interesses indígenas mas, sobretudo, nas políticas públicas formuladas pelo Estado Brasileiro destinadas ao bem estar dos silvícolas. Será realizado um resgate da legislação histórica de modo a melhor demonstrar as implicações advindas a partir das inovações constitucionais, revelando os desafios e perspectivas que ainda se descortinam na realidade do indígena brasileiro.
\end{abstract}

Palavras-chave: índios. Direito indigenista. Dignidade humana. Identidade cultural.

\section{THE INDIAN LAW IN BRAZIL: CHANGES AND INNOVATIONS FROM 1988 FEDERAL CONSTITUTION}

\begin{abstract}
Born amidst the Brazilian democratization process and strongly influenced by multicultural values, the Constitution of 1988 consolidated the Brazilian State neoconstitucional phenomenon , placing human dignity as its core value to radiate throughout the legal system . Essentially pluralistic, Constitution of 88 held an unprecedented transformation in the world of indigenous law, definitively abandoning the paradigm of cultural assimilation of Indians and recognizing their cultural identity as something inseparable from the realization of their human dignity . In this context, we will study the various changes in the Brazilian legal framework, with regard to guardianship of being indigenous, introduced from this constitutional reformulation that decisively influenced not only legislative action as the attitude of our courts when the resolution of sensitive issues involving indigenous interests , but especially in public policies formulated by the Brazilian government aimed at the welfare of forestry . A rescue of historic legislation in order to better demonstrate the implications arising from constitutional innovations, revealing the challenges and prospects still unveil the reality of Brazilian indians will be held.
\end{abstract}

Key-words: Indians. Indigenous law. Human dignity. Cultural identity.

\footnotetext{
${ }^{1}$ Doutoranda pela Universidade de Brasília (UNB). Mestre em Direito Constitucional pela
} UFRN. Professora da Universidade Federal Rural do Semi-Árido/RN. 


\section{INTRODUÇÃO}

Desde o período colonial e, a partir de então, por todo o período que se segue, durante a sociedade liberal do pós-revolução francesa e independência norte-americana, até o póssegunda guerra mundial, em período mais recente, os indígenas sempre foram considerados uma categoria fadada à extinção. Acreditava-se sinceramente que o melhor caminho para o índio ${ }^{1}$ seria a civilização, a inserção no ‘modus de vida’ civilizado e ‘evoluído’ que o índio necessariamente iria e desejaria se enquadrar, como processo natural de evolução humana e abandono da 'primitividade'.

Variava apenas o discurso: os colonizadores cristãos queriam catequizar como forma de 'salvar a alma dos aborígenes', os liberais intentavam a civilização dos 'primitivos', sua incorporação à sociedade envolvente e conseqüente abandono das tradições culturais. Todos esses argumentos conduziam a um único denominador comum: a aculturação dos índios, o abandono de sua forma de vida peculiar em favor da 'cultura dominante'.

Nesse contexto, para adentrarmos no universo dos direitos indígenas ${ }^{2}$ se faz indispensável compreendermos as modificações dogmáticas e filosóficas sofridas na tutela indigenista a partir da Constituição brasileira de 1988, quando o vetusto paradigma da assimilação cultural fora substituído pela proteção à diversidade cultural.

Tais transformações se devem à influência do neoconstitucionalismo e do multiculturalismo sobre a atual Carta brasileira, que acabou por se refletir decisivamente nas opções políticas adotadas pelo Ordenamento Jurídico Pátrio.

O novo constitucionalismo foi responsável pela interseção entre legalidade e valores axiológicos, tais como igualdade e dignidade humana, resultando em uma Constituição pluralista e multicultural, preocupada em resguardar direitos e interesses de minorias até então marginalizadas e relegadas à invisibilidade política no cenário nacional. Serão estudadas,

\footnotetext{
${ }^{1}$ Sem negligenciar as diferenças conceituais entre os termos índios, silvícolas, tapuios, aborígenes, autóctones, íncolas dentre outras formas utilizadas para designar o indígena, utilizaremos todas essas expressões como sinônimas, apenas para fins didáticos.

${ }^{2}$ Urge distinguir os termos "direitos indígenas" e "direito indigenista". O primeiro corresponde às normas de conduta interna, historicamente construídos por um determinado grupo indígena, seu direito costumeiro, consuetudinário; já o direito indigenista corresponde ao ramo do direito positivo voltado à regulação das relações existentes entre índios e Estado e entre índios e não-índios. Tendo consciência da diferença existente entre as duas nomenclaturas, e por razões meramente didáticas, optamos por fazer uso da expressão "direitos indígenas" para designar os direitos consagrados pelo ordenamento jurídico aos silvícolas do País, sinônimo à expressão 'direito indigenista'; quando nos reportarmos ao direito interno das comunidades índias lançaremos mão de termos como direito consuetudinário ou direito costumeiro.
} 
então, as influências que estas mudanças políticas e jurídicas exerceram sobre a Constituição brasileira de 1988 e sua inovadora abordagem na temática dos direitos indígenas.

Com o advento da Constituição de 88 abandonou-se à idéia de incorporação do índio à civilização, consagrando a proteção a sua identidade cultural, garantindo sua reprodução física e cultural, reconhecendo suas tradições, costumes, crenças, línguas, religião e, sobretudo, o direito a continuar a ser que sempre foram: índios, vivendo como índios. Além dos direitos culturais, ainda consagrou-se constitucionalmente o direito originário sobre as terras que habitam, estruturando um regime especialíssimo de posse e propriedade, com limitações expressas à atuação dos não-índios.

Ainda será abordada a proteção à diversidade cultural trazida pela Constituição de 1988, quando os índios ganharam proteção jurídica à reprodução de seus costumes e tradições históricas. O que antes era visto como uma situação transitória e fadada ao desaparecimento, com a Constituição de 88 elevou-se à categoria de patrimônio cultural brasileiro. Mais do que isso, a perpetuidade física e cultural dos índios e comunidades tradicionais elevou-se ao status de direitos fundamentais dessas populações, visto que inafastável da materialização de sua dignidade.

A partir dessas transformações políticas, jurídicas e filosóficas operou-se uma revolução sem precedentes no universo dos direitos indígenas, oportunizando uma reformulação completa na política indigenista oficial do Governo ${ }^{3}{ }^{4}$, nas diretrizes legais e na postura do Judiciário quando da resolução de delicadas questões envolvendo os interesses tapuios. Séculos de dominação, exclusão e imposição cultural ficaram para traz, ao menos juridicamente, proporcionando uma releitura de toda legislação nacional voltada à tutela do ser indígena.

Por fim, o presente ensaio realizará uma análise dos reflexos dessas transformações nas mais diversas áreas, tais como a capacidade civil indígena, exploração dos recursos minerais em suas terras, demarcação dos territórios tapuios e nas políticas públicas voltadas à educação silvícola. Para tanto será realizado um resgate histórico dos principais aspectos do direito indigenista, desde o período colonial até o processo de redemocratização brasileira que

\footnotetext{
${ }^{3}$ Mais informações no site da FUNAI, disponível em <http://www.funai.gov.br/index.php/nossas-acoes/povosindigenas-isolados-e-de-recente-contato?start=1>, acesso em 17 mar 2014.

${ }^{4}$ Para dar conta desses novos desafios, o Governo Federal deu início a uma ampla reformulação da política indigenista com a reestruturação da FUNAI e criação da Comissão Nacional de Política Indigenista - CNPI, importantíssimo espaço de articulação e formulação de políticas públicas destinadas à atender os povos indígenas. Informações em : <http://www.funai.gov.br/index.php/nossas-acoes/politica-indigenista?start=3>, acesso em 17 mar. 2014.
} 
culminou na Novel Carta constitucional, a fim de que seja demonstrado o desenvolvimento, transformação e consolidação de importantes institutos aplicados à tutela dos aborígenes.

\section{O ÍNDIO NO ORDENAMENTO JURÍDICO BRASILEIRO}

Estima-se que quando os Portugueses chegaram ao Brasil existiam aproximadamente 10 milhões de índios, derivados de quatro troncos étnicos diferentes: os Jês, os Caraíbas, os Maruaques e os Tupis, divididos em diversos grupos tribais que, por sua vez, se ramificavam (AFONSO DA SILVA, 2001, pag. 75).

Estima-se que mais de mil línguas eram faladas pelas populações aborígenes que aqui habitavam, a dificuldade de comunicação era tamanha que conduziu os jesuítas a tentar disseminar uma língua única, base do processo de catequese, culminando na estruturação do ñaguatu ('língua boa’) de base tupi-guarani, alguns termos sobrevivem até hoje sendo responsável pela falsa idéia de homogeneidade entre os diversos povos indígenas.

Importante não entender os índios como um segmento uniformizado da sociedade, como se todo indígena fosse igual. Se faz de fundamental importância a compreensão da diversidade cultural e étnica que distancia diversos grupos tribais entre si, da mesma forma como os não-índios se distanciam étnica e culturalmente dos aborígenes.

Vivem hoje no Brasil cerca 817.963 mil índios, distribuídos entre 220 povos, compondo cerca de 0,4\% da população nacional. Estima-se, ainda, que existam, em média, 82 grupos tribais ainda não catalogadas pelo órgão de assistência ao índio ${ }^{5}$, dos quais 32 já foram confirmados, e que pelo menos 180 línguas diferentes são faladas pelos membros dessas comunidades.

Comunidade indígena é aquela que se auto identifica como segmento distinto da sociedade nacional, em virtude da consciência de sua singularidade étnica e continuidade histórico-cultural, com origem e descendência pré-colombiana. O índio, por sua vez, é aquele que se considera pertencente a esta comunidade, e é por ela reconhecido como seu membro. Por tanto, pelo critério da auto-identificação, é o sentimento de pertinência a uma dada comunidade que faz do índio um índio. È índio quem se sente índio, quem dá continuidade a identidade étnica através da reprodução físico-cultural.

\subsection{0 índio e o indigenato: evolução e perspectivas}

\footnotetext{
${ }^{5}$ Informações segundo dados do senso de 2010. Disponível em:<http://www.funai.gov.br/>. Acesso em: 29 maio 2012.
} 
O indigenato consiste no reconhecimento do direito congênito dos índios sobre suas terras, um direito anterior e histórico, preexistente ao próprio sistema jurídico português e brasileiro e que, portanto, prevalecerá sobre qualquer outro direito que se pretenda sobre esses territórios tradicionais. É com base no indigenato, reafirmado pelo ordenamento jurídico nacional desde a época colonial, que se justifica a nulidade de todos os títulos existentes sobre as terras indígenas e a conseqüente retirada dos não-índios da região após a demarcação. É também com base neste instituto que o ato da demarcação possui feição meramente declaratória, não constituindo o direito dos índios sobre suas terras, mas apenas o declarando a fim de delimitar seus “domínios”.

Entretanto, há de se esclarecer que o indigenato apenas proclama o reconhecimento do direito de posse dos índios sobre as terras que tradicionalmente ocupam, uma vez que, no ordenamento jurídico brasileiro, nunca fora atribuída aos índios a propriedade de suas terras, mas apenas sua posse. O domínio das terras indígenas (TI) sempre esteve com a União ou com os Estados federados, nunca com os silvícolas.

O indigenato, portanto, serve para impedir que não-índios tentem usurpar os territórios tradicionais ou deles fazer uso, mas nunca limitou as pretensões estatais, verdadeiros senhores das terras indígenas, muito embora, a atual Constituição brasileira tenha imposto certas limitações às atividades do Estado em terras silvícolas, limitações que não existiam anteriormente, como a questão da mineração, da exploração dos recursos hídricos e naturais e, sobretudo, da vedação à retirada dos silvícolas de suas terras.

Como dito, o indigenato subsiste nos dias de hoje como uma herança do direito português que, através do Alvará Régio de 01/04/1680, ainda na época do Brasil colônia, atribuiu aos índios o direito originário sobre as terras que ocupavam apesar de a Coroa portuguesa permitir sua escravidão e determinar a sua catequese, numa clara intenção de integrá-lo à sociedade envolvente. Vigiam na época as Ordenações do Reino, que Portugal aplicava indistintamente à metrópole e à colônia, não tendo se dado ao trabalho de elaborar uma legislação própria, “as leis de índias”, a ser imposta aos povos ameríndios, tal como fez seus vizinhos espanhóis.

\subsubsection{Legislação histórica}

Roberto Lemos (2006, pag. 24) relata que a legislação do sec. XVI apregoava um bom tratamento aos tapuios que se submetessem à catequese, e guerra aos que se mostrassem inimigos. As Cartas Régias de 30/07/1609 e de 10/09/1611, afirmavam o pleno direito dos 
índios sobre suas terras, mas foi o Alvará Régio de 01/04/1680 que consagrou definitivamente o indigenato, reconhecendo aos índios os direitos originários sobre suas terras, não podendo, inclusive, as sesmarias concedidas por Portugal obstar tais direitos. A Carta Régia de 09/03/1718 ainda declarou que as nações indígenas não se submeteriam a jurisdição portuguesa, apesar de permitir sua escravização, revelando que os portugueses reconheciam a soberania e a autodeterminação dos povos ameríndios.

No Brasil império manteve-se o reconhecimento dos direitos dos índios sobre suas terras, bem como a permissão de sua escravidão (Carta Régia de 02/12/1808) ${ }^{6}$. A Constituição imperial, de 1824, nada mencionou acerca dos silvícolas, no entanto, o Ato Adicional à Constituição do Império, de 12/08/1832, determinou que caberia ao Governo a catequização e civilização dos índios. O Decreto de 30/06/1833, aliado ao Regulamento 143 de 15/03/1842, criou o sistema da tutela orfanológica, atribuindo aos juízes de órfãos poderes especiais em relação à pessoa e aos bens dos índios, capaz de elidir, inclusive, o pátrio poder, num claro reconhecimento da incapacidade do índio para gerir sua própria vida e seus bens ${ }^{7}$.

Com a Lei de Terras (Lei 601/1850) o território nacional fora dividido entre terras públicas, terras particulares e terras devolutas, estas que, dentre outras finalidades, se destinariam, na extensão necessária, à colonização dos indígenas ${ }^{8}$.

A primeira Constituição republicana, a de 1891, nada pronunciou acerca da situação dos índios no Brasil, entretanto, em seu art. 64 transferiu as terras devolutas para os Estados Federados, permanecendo com a União apenas aquelas necessárias à defesa das fronteiras e fortificações militares, assim como para a construção das estradas de ferro. Este dispositivo causou grande confusão uma vez que conduziu ao entendimento de que as terras indígenas haviam caído no domínio dos Estados, estes que acabaram por possibilitar seu esbulho e usurpação.

O fato agravou-se com a criação do Serviço de Proteção ao Índio (SPI) ${ }^{9}$, pelo Decreto 8.072 em 1910, que emitia "atestados de inexistência de índios”, possibilitando que os

\footnotetext{
${ }^{6}$ A Carta Régia de 05/11/1808 declarava guerra aos índios Botucudos do Paraná, então província de São Paulo, autorizando a servidão, daqueles tomados em cativeiro, pelo período de quinze anos. Da mesma forma, as Cartas Régias de 13/05/1808 e de 02/12/1808 declaravam guerra aos índios do Estado de Minas Gerais, bem como a servidão aos indígenas capturados. Maiores detalhes, vide Carlos Frederico Marés, 2008, pag..56.

${ }^{7}$ Carlos Frederico Marés (2008, pag. 92) conta a triste história da índia Helena que, considerada incapaz de gerir a própria vida apenas pelo fato de ser índia, perdeu a guarda de seu filho menor, Antônio Solimões, para um Juiz de Órfãos, em 25 de outubro de 1898, sob o argumento de que "era uma selvagem", "não dominando o português" e, "como conseqüência, não poderia gerir a sua própria vida, muito menos a de seu filho".

${ }^{8}$ Art. 12. "O Governo reservará das terras devolutas as que julgar necessárias: $1^{\circ}$, para a colonização dos indígenas (...)”.
} 
Estados membros concedessem títulos de domínio sem a devida verificação de existência, ou não, de índios na região ${ }^{10}$.

A criação do Serviço de Proteção ao Índio (SPI) voltava-se para a integração do índio ao modo de vida “civilizado” arrimado nas idéias liberais de que a humanidade apresentava níveis, ou etapas de desenvolvimento e que a condição dos índios seria precária e fadada ao desaparecimento após serem assimilados pela cultura “civilizada”. A política indigenista da época se baseava, assim, na civilização e aculturação dos índios. Deixava-se de lado a preocupação colonial com a catequização dos aborígenes para voltar-se para a civilização dos mesmos, segundo os padrões de uma sociedade moderna capitalista ocidental (FEIJÓ, 2010, pag. 52).

Percebe-se que, desde a época da colonização portuguesa, e até bem pouco tempo atrás, de uma forma ou de outra, buscava-se a aculturação do índio, seja pela catequese (sua dominação religiosa e espiritual) seja através do processo civilizatório, voltado à fazer do índio um legítimo cidadão (sua dominação cultural). Neste particular a criação do SPI baseava-se na integração dos povos indígenas à cultura nacional, na expectativa de acabar com as culturas indígenas transformando o índio em cidadão. Observe que a dizimação da cultura tapuia era, então, uma política oficial do Governo!

Entretanto, e contraditoriamente, o Decreto 8.072/1910 previa a demarcação das TI e o respeito à organização interna, hábitos e instituições das tribos.

Em seqüência, o Código Civil de 1916 põe fim a tutela orfanológica da época imperial determinando expressamente a incapacidade relativa dos índios para os atos da vida civil ${ }^{11}$, sujeitando-os ao regime tutelar a ser disciplinado em lei específica, salientando que esta incapacidade cessaria a medida que fossem se adaptando à civilização do País (parágrafo único). A regulação específica exigida pelo Estatuto civil veio em 1928, através do Decreto 5.484, que tratava da situação dos índios nascidos no território nacional e expressamente

\footnotetext{
${ }^{9}$ Inicialmente denominado Serviço de Proteção ao Índio e Localização de Trabalhadores Nacionais (SPILTN), transformou-se simplesmente em SPI em 1918, cuja direção fora atribuída ao Marechal Candido Mariano Rondon.

${ }^{10}$ Foi o que aconteceu ao povo Krenak, ou Borum, que além de sofrer guerra no Brasil colonial, ainda viu suas terras transformadas em devolutas pelo Estado de Minas Gerais e concedidas a terceiros. Em ação que durou mais de trinta anos, numa decisão histórica do STF, da relatoria do Min. Francisco Rezek, os Krenaks obtiveram o direito de voltar para suas terras. Da mesma forma, os Pataxós Hã Hã Hãe, da Bahia, brigam na justiça pela retomada de suas terras indevidamente usurpadas com o aval do Estado baiano. Vide, Boaventura de Souza Santos, Reconhecer para libertar: Os caminhos do cosmopolitismo multicultural. Rio de Janeiro:

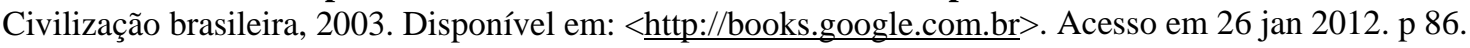

11 Art. 6. "São incapazes relativamente a certos atos ou a maneira de exercê-los: (...) III- Os Silvícolas. Parágrafo único. Os silvícolas ficarão sujeitos ao regime tutelar, estabelecido em leis e regulamentos especiais, o qual cessará à medida que se forem adaptando à civilização do País.”
} 
liberava os silvícolas da tutela orfanológica vigente nas Ordenações do Reino, reputando nulos os atos praticados pelos índios sem a devida representação do Estado, que na época se dava através do Serviço de Proteção ao Índio (FEIJÓ, 2010, pag. 52).

Em verdade, a extinção da tutela orfanológica pelo Código Civil de 1916, regulado pelo Decreto 5.484/1928, somente conduziu à transferência da gestão da pessoa do índio e de seu patrimônio do juiz de órfãos para o órgão indigenista, persistindo o equivoco da assimilação. Não se compreendia o direito a diferença, não havia o respeito à alteridade e ao direito do outro de escolher levar a vida que quisesse. Cegamente se pretendia extirpar a cultura tapuia do planeta, introduzindo o índio no nosso modo de vida, civilizando-o, como se essa fosse a única opção possível, como se a integração fosse a vontade desses povos.

A própria noção de civilização e capacidade foram conceitos construídos culturalmente, não se tratando de uma verdade universal e inquestionável. Foram os "brancos” que chegaram, invadiram, expulsaram e perseguiram aqueles que já estavam aqui desde tempos imemoriais, é a lei do "branco", ou seja, de uma cultura exógena, que diz que o índio não tem capacidade para reger sua própria vida por si só. Essas são leis dos “brancos” e não dos índios. Deve haver um respeito às instituições indígenas, suas tradições e modos de viver, possibilitando sua autodeterminação e escolhas de vida.

Foi a Constituição de 1934 a primeira Constituição brasileira a tratar dos direitos indígenas, assegurando ${ }^{12}$ a posse dos autóctones sobre as terras que permanentemente se achem localizados, vedada sua alienação, competindo à União a política indigenista nacional $^{13}$, que se voltava para a integração dos tapuios à comunhão nacional. A Constituição de 1937, também chamada de Constituição “polaca”, repetiu a disposição em seu artigo $154^{14}$.

O Decreto 5.540/1943 instituiu o dia 19 de abril como o dia nacional do índio. Por sua vez, o Decreto 58.824/1966 promulgou a Convenção 107 da Organização Internacional do Trabalho (OIT) voltada para a proteção e integração das populações indígenas e outras populações tribais. Tida por longo tempo como um dos mais importantes mecanismos internacionais de proteção aos interesses dos povos indígenas, com a mudança de mentalidade política e compreensão do direito à diversidade, a Convenção 107 acabou sofrendo resistência

\footnotetext{
${ }^{12}$ Art. 129. "Será respeitada a posse de terras de silvícolas que nelas se achem. permanentemente localizados, sendo-lhes, no entanto, vedado aliená-las”.

${ }^{13}$ Art. $5^{\circ}$ - "Compete privativamente à União: (...) XIX - legislar sobre: (...) m - incorporação dos silvícolas à comunhão nacional”.

${ }^{14}$ Art. 154. "Será respeitada aos silvícolas a posse das terras em que se achem localizados em caráter permanente, sendo-lhes, porém, vedada a alienação das mesmas”.
} 
e críticas por se conectar ao paradigma assimilacionista de civilização indígena, o que conduziu à revisão do instrumento e conseqüente derrogação por uma nova Convenção.

Assim, em 1989, o Convênio 169 da OIT veio substituir a malfadada Convenção 107, voltando-se para a efetivação da dignidade de povos indígenas e tribais, prezando pelo respeito à diferença cultual e autodeterminação dos povos autóctones. A Convenção 169 da OIT foi aprovada pelo Brasil apenas em 2002, através do Decreto Legislativo 143, e promulgada através do Decreto 5.051/2004.

A Constituição brasileira de 1946, em seu art. $216^{15}$, respeita a posse dos índios sobre suas terras desde que não sejam alienadas. Com a Constituição de 1967 as terras ocupadas pelos índios passaram a integrar o patrimônio da União ${ }^{16}$, sendo-lhes assegurado a posse permanente delas e o reconhecimento do usufruto exclusivo dos recursos naturais e das utilidades nelas existentes. Ainda no ano de 1967 fora extinto o SPI e criada como substituta a Fundação Nacional do Índio (FUNAI), através da Lei 5.371, atualmente responsável pela política indigenista nacional.

A Emenda Constitucional nº 1 de 1969, responsável pela modificação na Constituição de 67, manteve o reconhecimento do direito dos índios sobre suas terras e o usufruto exclusivo das riquezas naturais nelas encontradas ${ }^{17}$, bem como patrimônio da União, a quem compete legislar sobre a incorporação dos silvícolas à comunidade nacional ${ }^{18}$. Percebe-se que ainda nesta época predominava o paradigma da assimilação cultural e conseqüente incorporação do índio à sociedade “civilizada”.

Neste contexto foi editada a Lei 6.001/1973, o Estatuto do Índio (EI), revogando o Decreto 5.484/1928, porém mantendo o regime tutelar previsto no CC de 1916. O EI possui nítida inspiração integracionista, visando à gradativa incorporação do índio, como veremos mais detalhadamente nos itens que se seguem.

A Constituição Federal de 05/10/1988 constituiu verdadeiro marco no direito indigenista brasileiro uma vez que rompeu com o modelo integracionista de aculturação indígena. Das maiores conquistas da novel Constituição destaca-se o direito do índio a ser

\footnotetext{
${ }^{15}$ Art. 216. "Será respeitada aos silvícolas a posse das terras onde se achem permanentemente localizados, com a condição de não a transferirem”.

${ }^{16}$ Art. $4^{\circ}$. "Incluem-se entre os bens da União: (...) IV - as terras ocupadas pelos silvícolas".

${ }^{17}$ Art. 198. "As terras habitadas pelos silvícolas são inalienáveis nos têrmos que a lei federal determinar, a êles cabendo a sua posse permanente e ficando reconhecido o seu direito ao usufruto exclusivo das riquezas naturais e de tôdas as utilidades nelas existentes".

${ }^{18}$ Art. $8^{\circ}$. "Compete à União: (...)XVII - legislar sobre: (...) o - incorporação dos silvícolas à comunhão nacional”.
} 
índio e de perpetuar sua condição cultural peculiar, consistindo o direito à terra como mero instrumento do direito a reprodução física e cultural. A CF de 88 foi a primeira a tratar mais amiudamente da questão indígena, dedicando todo um capítulo à sua causa, merecendo, pois, um estudo mais pormenorizado, em capítulo específico, que se segue.

\subsection{O Brasil nos caminhos do multiculturalismo libertário}

A Constituição Federal (CF) de 1988 ao nascer no Ordenamento Pátrio vai dar seguimento a uma tendência surgida no início do século passado de elevar os direitos culturais ao status constitucional. Primeiramente positivada na Constituição mexicana de 1917 e em seguida na de Weimer (Alemanha) de 1919, os direitos culturais resumiam-se à proteção aos direitos autorais e a liberdade de expressão, bem aos moldes liberais de liberdades individuais (AFONSO DA SILVA, 2001, pag. 39).

Somente com a evolução do constitucionalismo, principalmente a partir da póssegunda guerra, e ascensão da dignidade humana como valor nuclear das Cartas constitucionais e inspiradora dos catálogos de direitos fundamentais foi que se percebeu a necessidade em dar proteção as formas culturais diferenciadas de certos grupos tradicionais, percebendo-se que garantir a dignidade humana para esses grupos significava dar proteção ao seu especial modo de vida, assegurando sua perpetuidade cultural.

Foi a partir daí que se passou a questionar o caráter universal dos direitos humanos, surgindo a dicotomia universalismo x relativismo cultural. O primeiro, correspondendo à visão clássica, compreendia que o conteúdo dos direitos fundamentais, seu significado, seria universal, válido para qualquer ser humano em qualquer contexto. Já os relativistas apontam a tendência da uniformidade como um aspecto da dominação cultural, imposta pela compreensão norte-americana e eurocentrista de mundo.

Deixando as polêmicas de lado, o fato é que a nossa Carta constitucional inspirada nas tendências de constitucionalização dos direitos culturais estruturou uma seção dedicada a cultura (arts. 215 e 216), estendendo sua proteção as manifestações das culturas populares indígenas e afro-brasileiras e de outros grupos formadores do processo civilizatório nacional, reconhecendo expressamente que as formas de expressão e manifestação cultural desses grupos consubstanciam o patrimônio cultural brasileiro, merecedor de proteção pelo Estado brasileiro.

A nova dogmática constitucional visa preservar a diversidade cultural do País, reconhecendo que o Brasil é uma nação multicultural e pluriétnica, formada por uma 
riquíssima variedade de populações tradicionais que merecem ter seu modo de vida secular e sua cultura singular preservados uma vez que contribuíram, e ainda contribuem, para a formação da identidade do povo brasileiro, consubstanciando nosso patrimônio cultural (art. 216).

Percebe-se, então, que o maior direito assegurado pela Carta aos silvícolas foi o direito a ser índio, reproduzindo sua cultura e tradições seculares, emergindo o direito à terra como um instrumento destinado a alcançar esse desiderato maior: a perpetuidade cultural indígena.

Aqui abro um parêntese para esclarecer que a perpetuidade cultural não significa uma intangibilidade ou um apartheid cultural, a convivência, mistura e influência de culturas diversas sempre foi um fato histórico, responsável pela reprodução cultural e pelo enriquecimento humano. A proteção constitucional à identidade cultural indígena não almeja a estagnação e o engessamento de culturas milenares como se fosse um museu vivo, mas apenas livrar da interferência ruinosa com que o Estado brasileiro atuou sobre esses grupos forçando um choque cultural e uma dominação vertical. Liberta-se enfim, o índio deixando que ele escolha o seu caminho.

\subsection{O indígena na Constituição Federal de 1988}

Inspirada por valores pluralistas e multiculturais a Constituição Federal (CF) de 88 realizou uma revolução sem precedentes na história brasileira de proteção ao indígena, substituindo o paradigma de assimilação social, orientador de toda a legislação anterior voltada aos silvícolas, por uma sólida proteção à sua singularidade étnica e cultural, reconhecendo que o índio está aqui para ficar, merecendo respeito e proteção pela sua condição peculiar.

Dessa forma, o aspecto mais marcante na Constituição brasileira, no que diz respeito à condição do índio, consiste em seu status jurídico diferenciado. A Constituição ainda foi a primeira a destinar um capítulo exclusivamente voltado para a disciplina dos direitos indígenas e a que mais se alongou sobre o tema, construindo um sólido sistema de proteção à identidade cultural dos autóctones.

Assim, reconhecendo a necessidade de preservação de uma minoria étnica nacional, a Constituição Federal (CF) estipulou uma série de direitos e garantias em prol da conservação da singularidade cultural indígena, perfilhando em seu art. 231 e parágrafos ${ }^{19}$, o direito dos

\footnotetext{
${ }^{19}$ Art. 231. "São reconhecidos aos índios sua organização social, costumes, línguas, crenças e tradições, e os direitos originários sobre as terras que tradicionalmente ocupam, competindo à União demarcá-las, proteger e
} 
índios em manter sua organização social, seus costumes, línguas, crenças e tradições, além de resguardar os direitos originários ${ }^{20}$ sobre as terras que tradicionalmente ocupam, assegurandoos o usufruto exclusivo das riquezas nelas existentes.

\subsubsection{O direito à terra e ao usufruto exclusivo}

A Constituição de 88 define as terras de tradicional ocupação silvícola como aquelas por eles habitadas em caráter permanente e as utilizadas para suas atividades produtivas, bem como aquelas imprescindíveis à preservação dos recursos naturais necessários ao seu bemestar e reprodução físico-cultural, conforme seus usos, costumes e tradições ${ }^{21}$. A Lei 6.001/1973 (Estatuto do Índio) ainda complementa as disposições constitucionais, assegurando o direito originário dos índios sobre as terras que ocupam independente de demarcação administrativa ${ }^{22}$.

Percebe-se que a Constituição assegura aos aborígines não só as terras que o grupo efetivamente ocupa, mas também aquelas indispensáveis a sua sobrevivência conforme os seus hábitos tradicionais, ambas denominam-se terras de ocupação tradicional ${ }^{23}$. Frisando que não se pode conceber a terra indígena apenas como aquela em que o grupo está fixado atualmente, posto que existem determinadas culturas aborígines que caracterizam-se pelo

fazer respeitar todos os seus bens. $\S 1^{\circ}$ - São terras tradicionalmente ocupadas pelos índios as por eles habitadas em caráter permanente, as utilizadas para suas atividades produtivas, as imprescindíveis à preservação dos recursos ambientais necessários a seu bem-estar e as necessárias a sua reprodução física e cultural, segundo seus usos, costumes e tradições. $\S 2^{\circ}$ - As terras tradicionalmente ocupadas pelos índios destinam-se a sua posse permanente, cabendo-lhes o usufruto exclusivo das riquezas do solo, dos rios e dos lagos nelas existentes (...)”.

${ }^{20} \mathrm{~A}$ expressão “Direitos originários sobre as terras que habitam” liga-se ao reconhecimento, pelo Ordenamento Jurídico brasileiro, da tradicional ocupação da terra pelos autóctones desde épocas imemoriais, que remontam à colonização do País, quando em $1^{\circ}$ de abril de 1680 o Alvará Régio os outorgou tal legitimidade. De lá para cá, a tendência nacional em todas as Constituições, foi a manutenção do reconhecimento de que o direito da posse indígena sobre suas terras é congênito, restando o Alvará de 1680 ainda em vigor, posto que nunca fora revogado, sendo constantemente invocado pela doutrina como legitimador do indigenato.

${ }^{21}$ Art. 231, § $1^{\circ}$ supracitado.

22 Art. 25. "O reconhecimento do direito dos índios e grupos tribais à posse permanente das terras por eles habitadas, nos termos do artigo 198, da Constituição Federal [1969], independerá de sua demarcação, e será assegurado pelo órgão federal de assistência aos silvícolas, atendendo à situação atual e ao consenso histórico sobre a antigüidade da ocupação, sem prejuízo das medidas cabíveis que, na omissão ou erro do referido órgão, tomar qualquer dos Poderes da República”.

${ }^{23}$ Não confundir as terras de tradicional ocupação indígena, previstas na Constituição Federal, com as Reservas indígenas previstas no Estatuto do Índio. Com efeito, as terras de ocupação tradicional são aquelas de ocupação histórica pelo grupo tribal, onde a comunidade estabeleceu, através de gerações, seus laços culturais e tradicionais, são as terras cuja posse lhes pertence em caráter originário, fruto do indigenato mencionado alhures. Já as Reservas indígenas são qualquer porção do Território Nacional que a União destina aos indígenas, para que lá vivam e reproduzam seus costumes sem, contudo, possuir uma ocupação tradicional e imemorial. 
nomadismo, sendo indispensável considerar toda a porção de terra na qual a comunidade periodicamente se desloca ${ }^{24}$.

Ao certificar o caráter originário da posse indígena sobre as terras que habitam a CF ainda admitiu a ancestralidade desse vínculo entre o índio e a terra, o que justifica a necessária proteção casada da terra e da cultura silvícola. Um direito originário, saliente-se, precede a qualquer outra forma de ocupação territorial, o que a CF avalizou mais adiante, no $\S 6^{\circ}$ do art. $231^{25}$, ao declarar que são nulos, não produzindo qualquer efeito jurídico, os atos que tenham por objeto a ocupação, o domínio e a posse das terras indígenas.

Isto porque o índio possui um relacionamento de intimidade para com o meio ambiente no qual se encontra inserido. Não é qualquer terra que reproduz uma cultura indígena, mas a "mãe-terra” na qual o índio nasceu e se criou, onde os seus antepassados conviveram e se encontram sepultados. O resgate histórico e espiritual do grupo conecta-se ao território habitado imemorialmente. Daí porque a Constituição veda a remoção dos grupos tapuios de suas terras tradicionais, o que somente será possível em face de catástrofe ou epidemia que ponha em risco a sobrevivência da própria tribo, ou no interesse da soberania do País ${ }^{26}$, após referendo do Congresso Nacional.

Tal dispositivo visa evitar que o Estado brasileiro veja no deslocamento de comunidades indígenas uma solução para seus projetos desenvolvimentistas, valendo a lembrança da odisséia vivida pelo povo Panará, os chamados “índios gigantes”, habitantes do norte do Mato Grosso: Por volta da década de 70, quando o governo militar encabeçava o Plano de Integração Nacional (PIN), fora dado início à construção da BR-163, rodovia

\footnotetext{
${ }^{24}$ É o caso da etnia yanomami, grupo indígena de tradicional ocupação da região montanhosa e de floresta na fronteira entre o Brasil e a Venezuela. Devido a pobreza do solo possuem grande mobilidade espacial e dispersão populacional uma vez que tendem a viver com baixa densidade demográfica em um mesmo local. Em geral, cada comunidade da etnia yanomami varia num percentual entre 50 à 80 habitantes que mantém intensa vida intercomunitária. Mas informações vide BARRETO, Helder Girão. Direitos indígenas. Vetores constitucionais. Curitiba: Juruá editora, 2008. Pág. 113.

${ }^{25}$ Art. 231, § 6 ${ }^{\circ}$. "São nulos e extintos, não produzindo efeitos jurídicos, os atos que tenham por objeto a ocupação, o domínio e a posse das terras a que se refere este artigo, ou a exploração das riquezas naturais do solo, dos rios e dos lagos nelas existentes, ressalvado relevante interesse público da União, segundo o que dispuser lei complementar, não gerando a nulidade e a extinção direito a indenização ou a ações contra a União, salvo, na forma da lei, quanto às benfeitorias derivadas da ocupação de boa fé”.

${ }^{26}$ Art. 231, § $5^{\circ}$ "É vedada a remoção dos grupos indígenas de suas terras, salvo, "ad referendum" do Congresso Nacional, em caso de catástrofe ou epidemia que ponha em risco sua população, ou no interesse da soberania do País, após deliberação do Congresso Nacional, garantido, em qualquer hipótese, o retorno imediato logo que cesse o risco”.
} 
Cuiabá-Santarém, que cortava ao meio o território Panará. As obras evoluíram sem que a FUNAI $^{27}$ implantasse um plano de proteção e assistência aos indígenas afetados.

Despreparados para intensificar o contato com os "brancos”, os índios Panarás foram dizimados em poucos meses, por epidemias de gripe e diarréia, pela disseminação da prostituição e do alcoolismo, sem contar com as invasões garimpeiras em seus domínios. Dos 300 indivíduos estimados em 1973, quando do contato oficial, em 1975, dois anos apenas, restaram 79 sobreviventes, foi então que a FUNAI resolveu transferir os Panarás para o Parque indígena do Xingu, área habitada por inimigos históricos dos Panarás, os kayapó ${ }^{28}$. De lá para cá grande foi a luta dessa gente no afã de retornar às suas terras originais, o que somente aconteceu em 1996, quando parte de seu antigo território foi oficialmente reconhecida através de Portaria do Então Ministro da Justiça, Nelson Jobim.

Com o auxílio dos advogados do Instituto Socioambiental (ISA), os “índios gigantes” acionaram a União e a FUNAI em demanda judicial que intentava uma indenização pelos danos materiais e morais sofridos em decorrência da construção da BR-163, em virtude das inúmeras mortes, do sofrimento, da dor e das humilhações sofridas por aquela gente. Pela primeira vez na história do Judiciário brasileiro fora reconhecido aos indígenas o direito à indenização por prejuízos provocados em decorrência de políticas públicas oficiais ${ }^{29}$.

Outra importante conseqüência advinda da originalidade da posse indígena é a demarcação, cujo dever de realização compete à União (art. 231, caput) ${ }^{30}$. A demarcação ${ }^{31}$ possui caráter meramente declaratório uma vez que a posse indígena é congênita e originária, não constituindo o direito dos aborígenes sobre suas terras, mas apenas declarando um direito preexistente, acarretando a extrusão de qualquer indivíduo não índio de seus territórios, sem

\footnotetext{
${ }^{27}$ Fundação Nacional do Índio. Órgão de assistência ao índio, componente da estrutura da administração pública federal.

${ }^{28}$ Quem conta com detalhes a saga dos índios gigantes é Boaventura de Souza Santos, Op. Cit. 2003. p. 89.

${ }^{29}$ A condenação do Estado brasileiro a pagar danos morais e materiais aos Panarás fora proferida pelo Juiz da $7^{\mathrm{a}}$ Vara da Justiça Federal de Brasília/DF, Novely Vilanova dos Reis, e posteriormente confirmada pelo Tribunal Regional Federal da $1^{a}$ Região. Maiores detalhes sobre a saga dos “índios gigantes”, vide: SANTOS FILHO, Roberto Lemos dos. Apontamentos sobre o direito indigenista. Curitiba: Juruá editora, 2006.Pág. 125.
}

\footnotetext{
${ }^{30}$ Ressalte-se que o art. 67 do Ato das Disposições Constitucionais Transitórias (ADCT), estipulou um prazo de cinco anos, a partir da promulgação da CF/88, para que a União realizasse a demarcação das TI brasileiras, prazo este, por óbvio, não observado.

${ }^{31}$ O procedimento de demarcação das TI está regulado pelo Decreto 1.775/1996 (já declarado constitucional pelo STF), sendo deflagrado por iniciativa do órgão federal de assistência ao índio, tramitando perante o Ministério da Justiça, aprovado por Portaria do Ministro da Justiça e, ao final, homologado por Decreto do Presidente da República, devendo ser registrado em cartório imobiliário e em livro próprio do Serviço do Patrimônio da União (SPU). O STF declarou, no caso Raposa Serra do Sol que o marco temporal adotado pela CF foi o de sua promulgação (05/10/88), ou seja, quando uma dada comunidade deveria estar habitando sua terra para fins de reconhecimento, a não ser que tenha sido esbulhada de sua posse, quando não tendo perdido o seu instinto de resistência conservará o seu direito.
} 
qualquer indenização, a não ser pelas benfeitorias derivadas da ocupação de boa-fé (art. 231, $\left.\S 6^{\circ}\right)$.

Com efeito, na oportunidade do julgamento da demarcação da terra indígena Raposa Serra do sol, em 2009, a Suprema Corte decidiu pela demarcação contínua da área, reconhecendo que a terra para os indígenas ostenta um caráter de ancestralidade e resgate histórico das tradições e simbolismos da comunidade, reconhecendo, ainda, a originalidade dos direitos aborígenes sobre suas terras, prevalecendo sobre qualquer outro título, inclusive sobre os pretensos direitos adquiridos de não-índios, reafirmando o caráter meramente declaratório da demarcação, revelando a sensibilidade com que a Corte se debruçou sobre a questão ${ }^{32}$.

O direito ao usufruto exclusivo compreende não só o direito à posse, uso e percepção das riquezas naturais e de todas as utilidades existentes em suas terras, como ainda

\footnotetext{
${ }^{32}$ Vejamos parte do voto do Ministro relator, Carlos Britto: (...)9. A DEMARCAÇÃO DE TERRAS INDÍGENAS COMO CAPÍTULO AVANÇADO DO CONSTITUCIONALISMO FRATERNAL. Os arts. 231 e 232 da Constituição Federal são de finalidade nitidamente fraternal ou solidária, própria de uma quadra constitucional que se volta para a efetivação de um novo tipo de igualdade: a igualdade civil-moral de minorias, tendo em vista o proto-valor da integração comunitária. Era constitucional compensatória de desvantagens historicamente acumuladas, a se viabilizar por mecanismos oficiais de ações afirmativas. No caso, os índios a desfrutar de um espaço fundiário que lhes assegure meios dignos de subsistência econômica para mais eficazmente poderem preservar sua identidade somática, linguística e cultural. Processo de uma aculturação que não se dilui no convívio com os não-índios, pois a aculturação de que trata a Constituição não é perda de identidade étnica, mas somatório de mundividências. Uma soma, e não uma subtração. Ganho, e não perda (...)11. O CONTEÚDO POSITIVO DO ATO DE DEMARCAÇÃO DAS TERRAS INDÍGENAS. (...) 11.2. O marco da tradicionalidade da ocupação. É preciso que esse estar coletivamente situado em certo espaço fundiário também ostente o caráter da perdurabilidade, no sentido anímico e psíquico de continuidade etnográfica. A tradicionalidade da posse nativa, no entanto, não se perde onde, ao tempo da promulgação da Lei Maior de 1988, a reocupação apenas não ocorreu por efeito de renitente esbulho por parte de não-índios. Caso das "fazendas" situadas na Terra Indígena Raposa Serra do Sol, cuja ocupação não arrefeceu nos índios sua capacidade de resistência e de afirmação da sua peculiar presença em todo o complexo geográfico da "Raposa Serra do Sol". (...) Terra indígena, no imaginário coletivo aborígine, não é um simples objeto de direito, mas ganha a dimensão de verdadeiro ente ou ser que resume em si toda ancestralidade, toda coetaneidade e toda posteridade de uma etnia. Donde a proibição constitucional de se remover os índios das terras por eles tradicionalmente ocupadas, assim como o reconhecimento do direito a uma posse permanente e usufruto exclusivo, (...) A Constituição de 1988 faz dos usos, costumes e tradições indígenas o engate lógico para a compreensão, entre outras, das semânticas da posse, da permanência, da habitação, da produção econômica e da reprodução física e cultural das etnias nativas. (...)12. DIREITOS "ORIGINÁRIOS". Os direitos dos índios sobre as terras que tradicionalmente ocupam foram constitucionalmente "reconhecidos", e não simplesmente outorgados, com o que o ato de demarcação se orna de natureza declaratória, e não propriamente constitutiva. Ato declaratório de uma situação jurídica ativa preexistente. Essa a razão de a Carta Magna havêlos chamado de "originários", a traduzir um direito mais antigo do que qualquer outro, de maneira a preponderar sobre pretensos direitos adquiridos, mesmo os materializados em escrituras públicas ou títulos de legitimação de posse em favor de não-índios. Atos, estes, que a própria Constituição declarou como "nulos e extintos" ( $\S 6^{\circ}$ do art. 231 da CF). 13. O MODELO PECULIARMENTE CONTÍNUO DE DEMARCAÇÃO DAS TERRAS INDÍGENAS. O modelo de demarcação das terras indígenas é orientado pela idéia de continuidade. Modelo bem mais serviente da ideia cultural e econômica de abertura de horizontes do que de fechamento em "bolsões", "ilhas", "blocos" ou "clusters", a evitar que se dizime o espírito pela eliminação progressiva dos elementos de uma dada cultura (etnocídio). STF. Tribunal Pleno. Pet. 3388/RR.
} 
proporciona o produto da exploração econômica de tais riquezas naturais ${ }^{33}$, sendo privativo dos indígenas as atividades de coleta, caça e pesca ${ }^{34}$. Vale dizer, então, que é proibido a qualquer indivíduo não-índio a exploração das riquezas naturais em terras indígenas, muito embora seja perfeitamente possível aos aborígines à exploração desses recursos naturais, ainda que com fins ao desenvolvimento de uma atividade economicamente útil, e não só para a mera subsistência.

Vale recordar que, no caso Raposa Serra do Sol, o Supremo Tribunal Federal deixou claro que o direito ao usufruto exclusivo não exclui a convivência entre índios e não-índios, sendo possível a abertura de vias e instalação de plataforma de fornecimento de serviços públicos, obstando por sua vez a possibilidade de os indígenas interditarem ou bloquearem as vias, cobrar pedágio ou inibir o regular funcionamento das repartições públicas. Da mesma forma, ao afirmar a compatibilidade entre terras indígenas e zonas de fronteiras, ressaltou a prerrogativa das forças armadas e da polícia militar em nelas adentrar e estabelecer suas bases sem necessidade de obter autorização de quem quer que seja.

Por oportuno, cabe introduzir o questionamento quanto a possibilidade, ou não, de os próprios índios poderem extrair as riquezas minerais de suas terras, o chamado "garimpo indígena”. A doutrina e alguns julgados já haviam se posicionado no sentido de diferenciar o garimpo indígena, técnica artesanal e de baixo impacto ambiental, da mineração industrial, incluindo a primeira como integrante do usufruto exclusivo destinado aos índios pela Constituição, com respaldo, ainda, no art. 44 do Estatuto do Índio ${ }^{35}$ que garante ao silvícola o direito exclusivo de exercer a garimpagem, a cata e a faiscação em suas terras.

Contudo, na oportunidade do julgamento da demarcação da terra indígena Raposa Serra do Sol, a Suprema Corte entendeu de modo diverso, esclarecendo que as atividades de mineração, garimpagem e faiscação não integram o direito de usufruto indígena das riquezas naturais existentes em suas terras, declarando indiretamente a não recepção pela nova ordem constitucional do art. 44 do EI, salientando que, caso queiram minerar em suas terras, deverão os autóctones obter a autorização de lavra garimpeira, tal como qualquer outro interessado.

Por outro lado, se a Constituição destina aos autóctones a posse plena das terras por eles habitadas e o usufruto de suas riquezas naturais, a propriedade dessas terras permanece com a União (art. 20, XI), nu proprietária, num regime suigeneris de posse e propriedade,

\footnotetext{
${ }^{33}$ Art. 23 e 24, caput, do EI.

${ }^{34}$ Art. 18, § $1^{\circ} \mathrm{c} / \mathrm{c}$ art. 24, § $2^{\circ}$ do EI. Ainda o STF, neste sentido, na Pet. 3388/RR.

35 Art. 44. “As riquezas do solo, nas áreas indígenas, somente pelos silvícolas podem ser exploradas, cabendolhes com exclusividade o exercício da garimpagem, faiscação e cata das áreas referidas”.
} 
cabendo às TI o papel de um bem público afetado permanentemente à uma finalidade pública: a habitação indígena e reprodução de sua cultura, sendo, inalienável e indisponível, inclusive pelos próprios índios ${ }^{36}$.

Inclusive, o usufruto exclusivo, concedido aos índios, das riquezas existentes em suas terras, cinge-se aos recursos contidos no solo, rios e lagos ( $\S 2^{\circ}$ do artigo 231), não abarcando o subsolo nem as jazidas minerais, que permanecem sob o domínio da União (art. 20, IX). Adiantamos, inclusive, que as jazidas minerais, inclusive as petrolíferas, constantes no subsolo brasileiro, máxime as que se encontrem sob terras indígenas, pertencem a União, não estando incluídas nas riquezas naturais de livre disposição dos silvícolas. Dessa forma, querendo, a União poderá dispor desses recursos minerais, explorando-o por sua própria conta ou concedendo sua exploração à empresa vencedora de certame licitatório.

Explica Carlos Frederico Marés (2008. Pág. 138) que a separação de domínio entre o solo e as riquezas do subsolo tem causado grande perplexidade entre os aborígines; afinal, como podem compreender que sejam senhores de suas terras, mas não do que está abaixo delas? Como é possível que os homens prospectem o petróleo que está no subterrâneo sem passar pela superfície? Perguntava incrédulo um cacique amazônico ante a possibilidade de a estatal francesa, Elf Aquitaine, explorar combustíveis fósseis em seu território.

A aplicação às terras indígenas, do sistema tradicional brasileiro de separação jurídica entre solo e subsolo, se torna algo demasiadamente arriscado ao pleno gozo dos direitos constitucionalmente assegurados aos autóctones, uma vez que implicará em restrições incontornáveis ao pleno exercício da posse territorial pela comunidade, consistindo, ainda, em uma ameaça à manutenção da exclusividade indígena do usufruto dos recursos naturais ali encontrados.

\subsubsection{Empreendimentos econômicos em terras indígenas}

No que tange à realização de empreendimentos econômicos em terras indígenas (TI) ${ }^{37}$ devemos observar duas situações distintas: A primeira refere-se à exploração de recursos naturais do solo, lagos e rios que fica proibida a qualquer não-índio, sendo nulo qualquer ato

\footnotetext{
${ }^{36}$ Art. 231, § $4^{\circ}$. "As terras de que trata este artigo são inalienáveis e indisponíveis, e os direitos sobre elas, imprescritíveis”.

${ }^{37}$ Saliente-se que a Portaria nº 281, de 20/04/2000, da Presidência da FUNAI, proíbe a exploração de qualquer atividade econômica ou comercial em terras ocupadas por índios isolados (aqueles sem qualquer contato, ou com pouco contato, para com a comunhão nacional).
} 
destinado à sua exploração, salvo relevante interesse público da União, segundo o que dispuser lei complementar ${ }^{38}$. Esta lei ainda não existe o que obsta, por obvio, a exploração dos recursos naturais das TI.

Por oportuno, lembre-se que tal dispositivo corresponde a uma norma constitucional de eficácia limitada, utilizando a cediça classificação estruturada por José Afonso da Silva (2008, passim ${ }^{39}$, dependente de uma norma ulterior que complete sua eficácia e aplicabilidade sem a qual resta inviabilizada em face da inexistência de regulação da matéria.

Quanto ao aproveitamento dos recursos hídricos, energéticos e das riquezas minerais em terras indígenas, a Constituição ${ }^{40}$ condicionou sua efetivação à autorização do Congresso Nacional, à oitiva das comunidades impactadas e à sua participação nos resultados da lavra, tudo na forma da lei, evidenciando, também, tratar-se de norma constitucional de eficácia limitada. Registre-se, aliás, que tal participação nos resultados da lavra constituirá fonte de renda indígena e será sempre coletiva, posto que visa compensar a limitação dos direitos constitucionalmente assegurados, sofrida por todos os membros da tribo.

As riquezas minerais e os potenciais de energia hidráulica, segundo a disciplina constitucional dos artigos 176, caput ${ }^{41}$, e 20, VIII e IX ${ }^{42}$, constituem, para fins de exploração e aproveitamento, propriedade distinta da do solo, pertencendo a União, que poderá explorálos mediante a outorga de concessão ou autorização para empresas brasileiras ou constituídas sob as leis brasileiras, com sede e administração no País, devendo a lei estipular condições

\footnotetext{
${ }^{38}$ Art. 231, § $6^{\circ}$. "São nulos e extintos, não produzindo efeitos jurídicos, os atos que tenham por objeto a ocupação, o domínio e a posse das terras a que se refere este artigo, ou a exploração das riquezas naturais do solo, dos rios e dos lagos nelas existentes, ressalvado relevante interesse público da União, segundo o que dispuser lei complementar, não gerando a nulidade e a extinção direito a indenização ou a ações contra a União, salvo, na forma da lei, quanto às benfeitorias derivadas da ocupação de boa fé”.

${ }^{39}$ José Afonso estrutura as normas constitucionais, segundo seu grau de eficácia, em três grupos: As normas de eficácia plena (aptas a produzir a plenitude de seus efeitos de imediato); as normas de eficácia contida (normas que, apesar de nascerem aptas a produzir seus efeitos de imediato, podem ter seu alcance restringido através de legislação ulterior); e as normas de eficácia limitada (normas que somente terão sua eficácia completa a partir de uma regulação legal posterior, exigida pela Constituição).
}

${ }^{40}$ Art. 231, § $3^{\circ}$. "O aproveitamento dos recursos hídricos, incluídos os potenciais energéticos, a pesquisa e a lavra das riquezas minerais em terras indígenas só podem ser efetivados com autorização do Congresso Nacional, ouvidas as comunidades afetadas, ficando-lhes assegurada participação nos resultados da lavra, na forma da lei".

${ }^{41}$ Art. 176. "As jazidas, em lavra ou não, e demais recursos minerais e os potenciais de energia hidráulica constituem propriedade distinta da do solo, para efeito de exploração ou aproveitamento, e pertencem à União, garantida ao concessionário a propriedade do produto da lavra".

${ }^{42}$ Art. 20. "São bens da União: (...)VIII - os potenciais de energia hidráulica; IX - os recursos minerais, inclusive os do subsolo; (...)" 
específicas quando essas atividades se desenvolverem em faixa de fronteira ou em terras indígenas ${ }^{43}$.

Todavia, as referidas leis (exigidas pelos artigos 231, $\S 3^{\circ}$ e $176, \S 1^{\circ}$ ) ainda não existem, havendo, apenas, alguns projetos em tramitação no Congresso Nacional, restando inviabilizada qualquer tentativa de se explorar o minério existente em terras indígenas ${ }^{44}$. Qualquer tentativa em contrário significará flagrante inconstitucionalidade. Ressalte-se que a Constituição não fez qualquer exigência quanto a espécie legal que deveria regular a atividade minerária em território índio, presumindo-se, por óbvio, que basta uma lei ordinária para satisfazer a vindicação constitucional, diferentemente, para a exploração das riquezas naturais contidas em TI exigiu Lei Complementar, além do relevante interesse público da União.

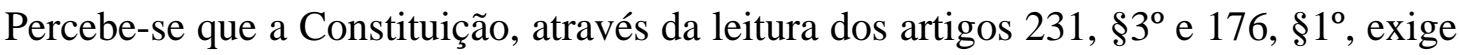
um regime diferenciado para a exploração minerária em terras indígenas, segundo requisitos preestabelecidos e exigindo lei que regule a matéria, afastando, pois, a incidência do Código de Mineração, voltado para a regulamentação da atividade minerária de maneira geral. Dentro deste modelo sui generis de exploração destaque-se que o único órgão competente para outorgar a pesquisa e a lavra minerária em terras indígenas é o Congresso Nacional, tornando o Departamento Nacional de Produção Mineral (DNPM), ou qualquer outro órgão, absolutamente incompetente para a referida atribuição.

Saliente-se também que a oitiva das comunidades impactadas pelo empreendimento minerário é condição sine qua non de validade da concessão de exploração mineral ou petrolífera, em território tapuio, haja vista que a Constituição Federal ao viabilizar a exploração mineraria nessas áreas de vulnerabilidade socioambiental assim o determinou. Qualquer burla à consulta das comunidades significa violação insanável da Constituição, viciando por completo a legitimidade da concessão deferida.

\footnotetext{
${ }^{43}$ Art. 176, $\S 1^{\circ}$. "A pesquisa e a lavra de recursos minerais e o aproveitamento dos potenciais a que se refere o "caput" deste artigo somente poderão ser efetuados mediante autorização ou concessão da União, no interesse nacional, por brasileiros ou empresa constituída sob as leis brasileiras e que tenha sua sede e administração no País, na forma da lei, que estabelecerá as condições específicas quando essas atividades se desenvolverem em faixa de fronteira ou terras indígenas."

${ }^{44}$ Não é, todavia, o que vem entendendo o DNPM (Departamento Nacional de Produção Mineral) que distribui, inconstitucionalmente, títulos de pesquisa e lavra de minérios em TI. Maiores informações acerca da questão, vide FEIJÓ, Julianne Holder da C. S. Exploração de petróleo em terras indígenas: À procura de um marco legal. Revista Direitos culturais. Programa de pós-graduação em direito - Mestrado da URI, Campus de Santo Ângelo/RS. Vol. 5. $\quad \mathrm{N}^{\mathrm{o}}$ 9. $\quad$ p. 157-178. julho/dezembro 2010. disponível em: $<$ http://srvapp2s.urisan.tche.br/seer/index.php/direitosculturais/issue/view/23>. Acesso em 02 junho 2011.
} 
Neste contexto, merece destaque a já mencionada Convenção 169 da Organização Internacional do Trabalho (OIT) que dentre outras coisas disciplina o direito de consulta às comunidades indígenas ante a possibilidade de qualquer fato que possa lhes afetar diretamente, desde medidas legislativas até à presença de empreendimentos econômicos em suas terras. Tendo sido devidamente ratificada e incorporada ao nosso ordenamento jurídico através do Decreto 5.051 de 2004, a Convenção 169/OIT deve ser observada e cumprida pelo Estado brasileiro que a vem negligenciando sistematicamente, já tendo inclusive sofrido repreensão da Organização das Nações Unidas (ONU) por sua displicência quanto aos direitos indígenas ${ }^{45}$.

Registre-se, outrossim, que a realização da audiência pública em face do procedimento de licenciamento ambiental não supre a exigência constitucional, primeiro porque não é voltada aos índios, mas a qualquer cidadão interessado no certame, segundo porque o IBAMA não possui competência para deflagrar o processo consultivo junto as comunidades indígenas.

\subsubsection{Capacidade civil e educação indígena}

Outra inovação trazida pela Novel Constituição foi o disposto no art. $232{ }^{46}$, que confere aos índios, suas comunidades e organizações legitimidade para ingressar em juízo em defesa de seus direitos e interesses, não exigindo representação ou assistência de quem quer que seja. Esse dispositivo põe fim ao retrogrado instituto do regime tutelar que vigia até então, com respaldo no Estatuto do Índio, e que considerava o autóctone um incapaz, devendo o órgão indigenista federal, assisti-lo em todas as situações sob pena de invalidade do ato.

Em verdade, o Estatuto do Índio reproduzia as normas constantes no Código Civil de 1916, que tratava o silvícola como relativamente incapaz, cessando a sua incapacidade a medida que fosse se adaptando à civilização do País, revelando a transitoriedade com que a condição indígena era tratada na época ${ }^{47}$. Protegia-se para integrar, acreditando-se

\footnotetext{
${ }^{45}$ Em setembro de 2010, a ONU emitiu um relatório chamando à atenção do Brasil pelo desrespeito aos direitos humanos dos povos indígenas e, sobretudo, pela inobservância do direito de consulta dos povos afetados pelo Complexo hidrelétrico de Belo Monte, no Rio Xingu, Estado do Pará.

${ }^{46}$ Art. 232. Os índios, suas comunidades e organizações são partes legítimas para ingressar em juízo em defesa de seus direitos e interesses, intervindo o Ministério Público em todos os atos do processo.

${ }^{47}$ De fato o projeto inicial do Código Civil de 1916, de autoria de Clóvis Beviláqua, não continha o dispositivo da incapacidade indígena, que fora introduzido pelo Senado. Com efeito, Beviláqua discordava da imposição do regime tutelar ao índio através do Código Civil, não só porque a regulação da capacidade civil indígena deveria constar de diploma específico, como pela estranheza em se imputar aos índios um regime tutelar de incapacidade, tradicionalmente destinado ao direito de família. Vide: SOUZA FILHO, Carlos Frederico Marés. O renascer dos povos indígenas para o direito. Curitiba: Juruá, 2008. p. 98.
} 
sinceramente que a integração fosse o melhor para o índio, e uma vez integrado o tapuio deixaria de ser índio e perderia os direitos inerentes a esta condição.

Esse quadro mudou a partir de 05 de outubro de 1988, quando o índio no Brasil passou a ter o direito a ser índio (SOUZA FILHO, 2008, pag. 107), não havendo mais o que se falar em incapacidade, mormente em face do art. 232 supra mencionado (BARRETO, 2008, pag. 40), fazendo bem o novo Código Civil em deixar a temática para a legislação específica (art. $4^{\text {, }}$, parágrafo único). Não se objetiva mais a incorporação do silvícola ao nosso modus vivendi, pelo contrário, protege-se o seu direito de viver conforme suas tradições culturais, a viver como índio. Registre-se, por oportuno, que este é o entendimento pacífico do Superior Tribunal de Justiça (STJ).

Saliente-se que deve o Ministério Público (MP) intervir em todos os atos do processo como custos legis. Aliás, além dos índios e suas comunidades e organizações, também a União (através da FUNAI) e o Parquet, possuem legitimidade para defender em juízo os interesses indígenas. A primeira em razão da tutela-proteção estabelecida no caput do art. 231, o segundo em virtude do dever institucional previsto no art. 129, $\mathrm{V}^{48}$.

Se faz de bom alvitre não confundir a tutela incapacidade - presente na legislação anterior e que não fora recepcionada pela novel Carta por se arrimar no paradigma da assimilação cultural - com a tutela-proteção, ainda presente na Constituição de 88, em seu art. 231 caput, ao determinar o dever da União de zelar pelos direitos e bens dos indígenas.

De fato, tudo o mais que reporta aos indígenas fora atribuído, pela Constituição, à União, seja a demarcação de suas terras, seja a propriedade delas, seja a competência para legislar ${ }^{49}$, seja a competência da justiça federal para julgar as disputas envolvendo seus direitos ${ }^{50}$, nada mais coerente, por tanto, que a proteção dos bens indígenas coubesse também à União, nada mencionando o dispositivo a cerca do retrogrado regime tutelar inaugurado no CC de 1916 e perpetuado pelo Estatuto do Índio.

Além do mais, a atribuição de legitimidade às organizações e comunidades indígenas de ingressarem em juízo na defesa de seus direitos, sem exigir qualquer representação para tanto, deixa clara a intenção do Legislador Constituinte em abandonar definitivamente o anacrônico regime tutelar do EI.

\footnotetext{
48 Art. 129. "São funções institucionais do Ministério Público (...) V - defender judicialmente os direitos e interesses das populações indígenas (...)”.

${ }^{49}$ Art. 22. “Compete privativamente à União legislar sobre: (...) XIV - populações indígenas”.

${ }^{50}$ Art. 109. “Aos juízes federais compete processar e julgar: (...) XI - a disputa sobre direitos indígenas”.
} 
Outro importante direito assegurado aos índios pela Constituição refere-se ao disposto no $\S 2^{\circ}$ do artigo 210, que garante, quando do ensino fundamental, a utilização da língua materna indígena juntamente ao português, e da manutenção dos processos próprios de aprendizagem. O dispositivo consagra o bilingüismo e torna coerente as proposições da própria Constituição, tendo de um lado a educação, um direito de todos inclusive indígenas, por outro a conservação e valorização de seus costumes e tradições históricas. Dessa norma deflui importantes diretrizes e implicações na formulação de políticas públicas voltadas à satisfação do direito indígena à educação ${ }^{51} 52$.

Saliente-se que, segundo dados do IBGE (censu 2010), divulgados pela FUNAI ${ }^{53}$, recentemente foram registradas 274 línguas indígenas faladas no País, sendo que, dos 817.963 índios que vivem no Brasil, 17,5 \% não falam o português.

O fornecimento de educação talvez tenha sido a primeira questão a despertar o interesse e a preocupação do Estado Brasileiro para com a situação dos índios, entretanto, de início essa preocupação voltava-se para a catequização e conversão ao cristianismo e, posteriormente, para uma incorporação do índio à sociedade envolvente.

A primeira escola indígena data de 1922, a "escola rural mista do posto indígena de Simões Lopes”, na terra indigna Bakairí, Mato Grosso, cujo objetivo era “civilizar” os índios, ensinando-lhes o português, num processo de assimilação cultural que visava, sobretudo, a formação de mão de obra para serviços como o de tropeiro, carpinteiro e oleiro e que, mesmo assim, somente estava disponível aos homens ${ }^{54}$. Era a época do extinto Serviço de Proteção ao Índio (SPI), antecessor da FUNAI.

\footnotetext{
${ }^{51}$ Hodiernamente existem mais de duas mil escolas indígenas, nas quais lecionam cerca de sete mil professores, sendo $85 \%$ deles de origem indígena, atendendo a quase cento e cinqüenta mil estudantes, a maioria no Ensino Fundamental. Dessas escolas, vinte e quatro oferecem também o Ensino Médio, e apenas sete têm laboratórios de informática. Mais informações, vide: DREYER, Diogo. A realidade da educação indígena. Disponível em: <http://www.educacional.com.br/entrevistas/entrevista0110.asp>. Acesso em 07 out. 2011.

52 Ressalte-se que as ações promovidas e acompanhadas pela FUNAI no campo dos direitos sociais indígenas dirigem-se aos povos em contato com a sociedade nacional. Informações em: < http://www.funai.gov.br/index.php/nossas-acoes/direitos-sociais>, Acesso em 17 mar. 2014.

${ }^{53}$ Disponível em: < http://www.funai.gov.br/index.php/indios-no-brasil/quem-sao>, acesso em 17 mar 2014.

54 TAUKANE. Darlene Iaminalo. Avanços e impasses na educação escolar indígena: A experiência dos KurâBakairi. In: VEIGA, Juracilda; SALANOVA, André (Orgs.). Questões de educação escolar indígena: da formação do professor ao projeto de escola. Brasília: FUNAI/DEDOC, Campinas/ALB, 2001. Disponível em: <http://www.funai.gov.br/projetos/Plano_editorial/Pdf/Questoes_de_educacao_escolar_indigena.pdf >. Acesso em 25/09/2011. p. 13-23.
} 
A educação indígena deverá voltar-se ao fortalecimento das tradições culturais do grupo étnico ${ }^{55}$, discutindo e conscientizando os alunos quanto aos problemas, dilemas e dificuldades da sua gente, trabalhando os conhecimentos tradicionais e explorando a escrita em sua língua materna, deixando o português como segunda língua, acessória, um instrumento de comunicação intercultural. Infelizmente a prática revela que muitas escolas indígenas resumem o bilingüismo ao simples convívio do português com a língua nativa, utilizando esta apenas como mecanismo de rápida alfabetização no português, conduzindo, muitas vezes à perda da língua materna ${ }^{56}$.

\section{CONSIDERAÇÕES FINAIS}

A consagração da teoria dos direitos fundamentais, somada a valorização da dignidade humana que ela encerra, acabou por proporcionar uma releitura da moderna conotação de Estado (ocidental saliente-se) proporcionando a consolidação do chamado Estado Constitucional, que além da força normativa da Constituição elevou a dignidade humana à valor supremo à se irradiar por todo o ordenamento jurídico, justificando a constitucionalização de um vasto rol de direitos fundamentais voltados à concretização de uma vida em dignidade para todos os seres humanos do planeta.

Ao passar do tempo, contudo, percebeu-se que essa vida em dignidade não alcançaria o mesmo significado em todas as culturas humanas espalhadas pelo Globo e que o primeiro passo a fim de se garantir isonomia para todos seria através do reconhecimento do direito a diferença. Desenvolvia-se assim os ideários do que viria a ser chamado de multiculturalismo, o reconhecimento de que no mundo existem diversas culturas singulares e seculares que convivem e se influenciam em um processo multicultural, sendo o respeito à essa identidade étnica e cultural o único caminho para se alcançar a dignidade desses povos.

Tais ideários refletem a realidade dos diversos países latino-americanos, sobretudo o Brasil, que possuem um tabuleiro social altamente diversificado, composto por um riquíssima

\footnotetext{
55 Saliente-se que os povos Indígenas possuem seus processos educativos próprios, que ocorrem em diferentes espaços e tempos de ensino e aprendizagem, de acordo com as suas culturas e tradições, relacionados à transmissão de conhecimentos e técnicas, atividades tradicionais, rituais, modos próprios de manejo dos recursos naturais e de gestão do território, produção do artesanato, entre outros conhecimentos particulares de cada grupo específico. Informações em: < http://www.funai.gov.br/index.php/processos-educativos-comunitarios> , Acesso em 17 mar. 2014.

${ }^{56}$ GUIMARÃES, Suzana Grillo. A formação do professor indígena no Brasil hoje. P. In: VEIGA, Juracilda; SALANOVA, André (Orgs.). Questões de educação escolar indígena: da formação do professor ao projeto de escola. Brasília: FUNAI/DEDOC, Campinas/ALB, 2001. Disponível em:

<http://www.funai.gov.br/projetos/Plano_editorial/Pdf/Questoes_de_educacao_escolar_indigena.pdf >. Acesso em 15/09/2011. Acesso em 25 set. 2011. p. 97-129.
} 
gama de comunidades tradicionais, dentre elas as indígenas, que vivem em suas tradições, resistindo bravamente às tentativas ferozes de aculturação e 'civilização', lutando contra a invisibilidade política e jurídica com que foram tratados desde o período colonial.

No Brasil, esse contexto de dominação cultural institucionalizada se modificou com a Constituição Federal de 88, quando a consolidação do Neoconstitucionalismo no País, fruto do processo de redemocratização, vivido pós-ditadura militar, trouxe consigo os valores da dignidade humana sob a influência do multiculturalismo, resultando em uma Constituição pluralista e cosmopolita, operadora de uma transformação sem precedentes no universo dos direitos indigenistas.

A atual Carta rompeu definitivamente com o paradigma da assimilação cultural, passando a reconhecer a diversidade cultural do País, garantindo a sua reprodução e perpetuidade. A CF de 88 destinou um capítulo inteiro à proteção do ser indígena, resguardando suas tradições, línguas e culturas, reafirmando o indigenato e, pela primeira vez na história jurídica brasileira, garantindo ao índio o direito a continuar sendo índio, vivendo como índio, e não como 'brancos', sem catequização, sem civilização, sem processo de incorporação.

A partir de então, operou-se uma profunda transformação na abordagem da questão indígena no Brasil, tanto na atividade legislativa quanto no posicionamento dos Tribunais mas, sobretudo, na elaboração das políticas públicas necessárias ao seu bem-estar. Vimos, porém que essas mudanças ainda não foram concluídas, existindo um longo caminho a ser perfilhado antes que os direitos assegurados aos índios pelas CF se vejam efetivados em sua plenitude. O mais difícil, no entanto, é desmistificar o preconceito arraigado no imaginário social do País, incapaz de compreender e aceitar a diversidade étnica e cultural.

\section{REFERÊNCIAS}

BARBOSA, Carla Gonsalves Antunha; BARBOSA, Marco Antônio; BARBOSA, João Mítia Antunha. Direito a diferença na sociedade da informação: Os direitos indígenas na Constituição brasileira. Revista do Instituto dos Advogados de São Paulo. vol. 20. São Paulo, 2007.

BARRETO, Helder Girão. Direitos indígenas: Vetores constitucionais. Curitiba: Juruá Editora, 2008.

BARROSO, Luiz Roberto. Neoconstitucionalismo e Constitucionalização do direito (O triunfo tardio do Direito Constitucional no Brasil). In: NETO, Cláudio Pereira de Souza; 
SARMENTO, Daniel. A constitucionalização do direito: fundamentos teóricos e aplicações específicas. Rio de Janeiro: Lúmen Júris, 2007.

BÔAS. Hariessa Cristina Villas. Mineração em terras indígenas: A procura de um marco legal!. Rio de Janeiro: Editores Roberto C. Villas Boas e Arsênio Gonzáles Martinez, 2005. Disponível em: <http://books.google.com.br>. Acesso em 20 mar. 2009.

BONAVIDES, Paulo. Curso de direito constitucional. 13ª ed. São Paulo: Malheiros, 2003.

BOTELHO, Marcos César. Os povos indígenas e o direito a terra: O Supremo tribunal Federal e o julgamento da demarcação da terra Raposa Serra do Sol. In: SIQUEIRA, Dirceu Pereira; BELINATI, Miguel (Coord.). Inclusão social e direitos fundamentais. São Paulo: Boreal editora, 2009. p. 261-277.

CASTRO, Carlos Roberto Siqueira. A constituição aberta e os direitos fundamentais Ensaios sobre o constitucionalismo pós-moderno e comunitário. Rio de Janeiro: Forense, 2005.

CUNHA, Manoela Carneiro da. O futuro da questão indígena. In: Estudos avançados. São Paulo, abr. 1994. p. 121-136. Disponível em:

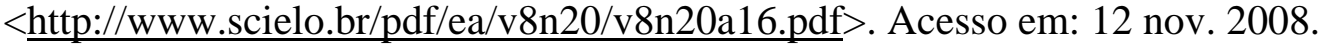

DREYER, Diogo. A realidade da educação indígena. Disponível em:

<http://www.educacional.com.br/entrevistas/entrevista0110.asp>. Acesso em 07 out. 2011.

FEIJÓ, Julianne Holder da Câmara Silva; SILVA, Maria dos Remédios Fontes. Proteção à identidade indígena e quilombola: Uma análise à luz do multiculturalismo e da abertura constitucional. Revista Constituição e garantia de direitos. Natal:Vol. 04, ano II, Fev-Ago, 2011. Disponível em:

<http://www.ccsa.ufrn.br/ojs/index.php/PPGD/issue/view/40/showToc>.

FEIJÓ, Julianne Holder da Câmara Silva. Proteção à identidade cultural no contexto do Neoconstitucionalismo e da abertura constitucional. Artigo publicado nos anais do Congresso Lusobrasileiro de direito do patrimônio cultural. Ouro Preto, Mar. 2011.

A casuística latino-americana de exploração de petróleo em terras indígenas: o desafio da concretização dos direitos humanos em prol das comunidades impactadas. Revista Direito E-nergia. Ano II, $2^{\text {a }}$ Ed. Natal-RN: Janeiro-junho, 2010. Pags. 1-20. ISSN 2175-6198. Disponível em: <http://www.ccsa.ufrn.br/ojs/index.php/DireitoEnergia/article/viewFile/33/69>. Acesso em: 12 ago. 2010.

.Aspectos jurídicos acerca da exploração e produção de petróleo e gás natural em terras indígenas. 2009, $96 \mathrm{f}$. Monografia (Bacharelado em Direito) - Universidade Federal do Rio Grande do Norte, Natal, 2009.

Exploração de petróleo em terras indígenas: À procura de um marco legal.

Revista Direitos culturais. Programa de pós-graduação em direito - Mestrado da URI, Campus de Santo Ângelo/RS. Vol. 5. No 9. p. 157-178. julho/dezembro 2010. disponível em:

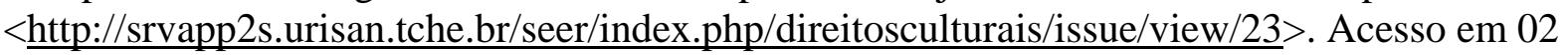
junho 2011. 
FERRAREZO FILHO, Paulo. O multiculturalismo nos limites da universalização dos direitos humanos e a emergência de um projeto de solidariedade. In: Direitos Culturais. Disponível em:

$<\underline{\text { http://srvapp2s.urisan.tche.br/seer/index.php/direitosculturais/article/view/23/17.Acesso }>}$ em: 03 out. 2010.

FUNDAÇÃO NACIONAL DO ÍNDIO. Índios do Brasil. Disponível em: $<$ http://www.funai.gov.br/> . Acesso em 04 fev. 2012.

Povos indígenas isolados e de recente contato. Disponível em <

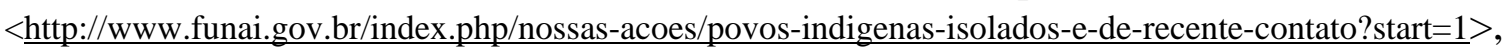
acesso em 17 mar. 2014.

Política indigenista. Disponível 1m < $\underline{\text { http://www.funai.gov.br/index.php/nossas-acoes/politica- }}$ indigenista?limitstart=0>, Acesso em 17 mar. 2014.

Direitos Sociais. Disponível em < $<$ http://www.funai.gov.br/index.php/nossas-acoes/direitossociais>, acesso em 17 mar. 2014.

Educação comunitária. Disponível em: < http://www.funai.gov.br/index.php/processoseducativos-comunitarios>, acesso em: 17 mar. 2014.

GUIMARÃES, Suzana Grillo. A formação do professor indígena no Brasil hoje. P. In: VEIGA, Juracilda; SALANOVA, André (Orgs.). Questões de educação escolar indígena: da formação do professor ao projeto de escola. Brasília: FUNAI/DEDOC, Campinas/ALB, 2001. Disponível em:

<http://www.funai.gov.br/projetos/Plano_editorial/Pdf/Questoes_de_educacao_escolar_indige na.pdf $>$. Acesso em 15/09/2011. Acesso em 25 set. 2011. p. 97-129.

HESSE, Konrad. A força Normativa da Constituição. Porto Alegre: Fabris Editor, 1991. Tradução de Gilmar Ferreira Mendes.

Constitución y Derecho Constitucional. In: : BENDA, Ernst; MAIHOFER, Werner; VOGEL, Hans-Jochen; HESSE, Konrad; HEYDE, Wolfgang. Manual de Derecho

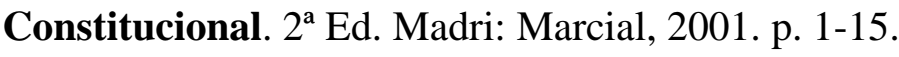

Significado de los derechos fundamentales. In: BENDA, Ernst; MAIHOFER, Werner; VOGEL, Hans-Jochen; HESSE, Konrad; HEYDE, Wolfgang. Manual de derecho constitucional. $2^{\text {a }}$ Ed. Madrid: Marcial, 2001, p. 63-115.

INSTITUTO SOCIOAMBIENTAL. Consulta livre, prévia e informada na Convenção 169 da OIT. Disponível em: <http://www.socioambiental.org/inst/esp/consulta_previa $>$. Acesso em: 10 ago. 2010.

Especial Belo Monte - A polêmica da usina de Belo Monte. Disponível em: $<$ http://www.socioambiental.org/esp/bm/index.asp>. Acesso em 10 nov. 2010. MATHIAS, Fernando; YAMADA, Erika. Declaração da ONU sobre direitos dos povos indígenas. Disponível em:

$<$ http://pib.socioambiental.org/pt/c/direitos/internacional/declaracao-da-onu-sobre-direitosdos-povos-indigenas $>$. Acesso em: 11 nov. 2010. 
MELLO, Celso Antônio Bandeira de. Conteúdo jurídico do princípio da igualdade. $3^{\mathrm{a}}$ ed. São Paulo: Malheiros, 2008.

MIRANDA, A. Gursen de. Coordenador. O direito e o índio. Belém: Editora Cejup, 1994.

MIRANDA, Jorge. Manual de Direito Constitucional. Tomo II. $4^{\mathrm{a}}$ ed. Coimbra: Coimbra editora, 2000.

MOTA, Marcel. Pós-positivismo e restrições de direitos fundamentais. Fortaleza: OMNI Editora, 2006.

NOBRE JÚNIOR. Edilson Pereira. Terras indígenas e aproveitamento de recursos hídricos para fins de exploração energética. In: XAVIER, Yanko Marcios de Alencar e outros (Org.). Energia e Constituição. Ceará: Konrad Adenauer, 2009. p. 83-109.

PEREIRA, Micheli. Direitos humanos: Univesalismo, indivisibilidade e democracia liberal X Relativismo cultural, globalização e democracia 'agonísta'. Revista Direitos culturais. Programa de pós-graduação em direito - Mestrado da URI, Campus de Santo Ângelo/RS. Vol. 5. No 9. p. 13-33. julho/dezembro 2010. disponível em:

$<$ http://srvapp2s.urisan.tche.br/seer/index.php/direitosculturais/issue/view/23 > . Acesso em 29 junho 2011.

PIOVERSAN, Flávia. Direitos Humanos e o Direito Constitucional Internacional. $11^{\mathrm{a}}$ ed. São Paulo: Saraiva, 2010.

RICARDO, Fany; ROLLA, Alicia (Org). Mineração em Terras Indígenas na Amazônia brasileira. Instituto Socioambiental: São Paulo, 2005.

ROCHA, Ana Flávia (Org.). A defesa dos direitos socioambientais no judiciário. São Paulo: Instituto socioambiental (ISA), 2003.

SANTILLI, Juliana. Socioambientalismo e novos direitos: Proteção jurídica à diversidade biológica e cultural. São Paulo: Editora Peirópolis, 2005.

Aplicação das normas ambientais às terras indígenas e superposição de unidades de conservação com terras indígenas. Revista de Direito Ambiental. Vol. 12. 1998.

SANTILLI, Márcio. Terras indígenas na Amazônia brasileira: Subsolo bloqueado por interesses minerários In: RICARDO, Fany (Org.). Interesses minerários em terras indígenas na Amazônia legal brasileira. Doc. N06 do Instituto Socioambiental. Jul. 1999. Disponível em: < http://www.socioambiental.org/banco_imagens/pdfs/14.pdf $>$. Acesso em: 12 ago. 2010. p. 81-89.

SANTOS, Boaventura de Sousa (Org.). Reconhecer para libertar: Os caminhos do cosmopolitismo multicultural. Rio de Janeiro: Civilização brasileira, 2003. Disponível em: <http://books.google.com.br>. Acesso em 26 jan 2012. 
Por uma concepção multicultural dos direitos humanos. Rio de Janeiro: Contexto internacional, jan./jun. 2001. Vol. 23. p. 7-34. disponível em:

$<$ http://www.boaventuradesousasantos.pt/media/pdfs/Concepcao_multicultural_direitos_hum anos_ContextoInternacional01.PDF>. Acesso em: 22 maio 2011.

SANTOS FILHO, Roberto Lemos dos. Apontamentos sobre o direito indigenista. Curitiba: Juruá editora, 2006.

Índios, Convenção n 169 da OIT e o meio ambiente. Jus Navigandi, Teresina, ano 10, n. 1074, 10 jun. 2006. Disponível em:

<http://jus2.uol.com.br/doutrina/texto.asp?ID=8499>. Acesso em 25 jan. 2009.

SILVA, Américo Luís Martins da. Populações indígenas ou tradicionais. In: Direito do meio ambiente e dos recursos naturais. V. III. São Paulo: Editora Revista dos Tribunais - RT, 2006. P. 138/219.

SILVA, José Afonso da. Curso de direito constitucional positivo. 24. ed. São Paulo: Malheiros, 2005.

Aplicabilidade das normas constitucionais. São Paulo: Malheiros, 2008.

. Ordenação constitucional da cultura. São Paulo: Malheiros, 2001.

SOUZA FILHO, Carlos Frederico Marés de. O renascer dos povos indígenas para o direito. Curitiba: Juruá Editora, 2008.

SOUZA FILHO, Carlos Frederico Marés de; ARBOS, Kerlay Lizane. Mineração em Terras indígenas, Direitos Humanos e o Sistema Interamericano de Direitos Humanos.

Disponível em:

< http://srvapp2s.urisan.tche.br/seer/index.php/direitosculturais/article/viewFile/30/24> .

Acesso em: 10 ago. 2010.

SUPREMO TRIBUNAL FEDERAL. Pesquisa de jurisprudência. Disponível em: $<$ http://www.stf.jus.br/portal/jurisprudencia/pesquisarJurisprudencia.asp > . Acesso em: 17 maio 2011.

TAUKANE. Darlene Iaminalo. Avanços e impasses na educação escolar indígena: A experiência dos Kurâ-Bakairi. In: VEIGA, Juracilda; SALANOVA, André (Orgs.). Questões de educação escolar indígena: da formação do professor ao projeto de escola. Brasília: FUNAI/DEDOC, Campinas/ALB, 2001. Disponível em:

$<$ http://www.funai.gov.br/projetos/Plano_editorial/Pdf/Questoes_de_educacao_escolar_indig ena.pdf>. Acesso em 25/09/2011. p. 13-23.

TRIBUNAL REGIONAL FEDERAL DA PRIMEIRA REGÃO. Pesquisa de jurisprudência. Disponível em: <http://www.trf1.gov.br/default.htm>. Acesso em: 13 ago. 2010.

VALLE, Raul Silva Telles do. Mineração na Amazônia e terras indígenas. Disponível em:

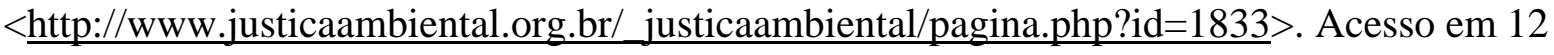
ago. 2010. 
